\title{
Congenital Anomalies in Thi-Qar: A Recent Observational Study during 2019
}

\author{
Dr. Jabbar Badr Mohan ( Consultant paediatrician, FICMS ) \\ Dr.Mohammed Aziz Katie ( DCh ) \\ Dr.Rikan Mohsen Zugair $\quad$ ( DCh )
}

\begin{abstract}
Background: congenital anomalies are a significant but under recognized cause of disability and mortality among infants and children under the age of five years. They can be life-threatening conditions, result in long-term disability, and negatively affect health - care system, societies, families and individual (2).
\end{abstract}

Objectives: to estimate the prevalence of congenital malformations in our locality Thi-Qar province, most common type and any responsible factors for these anomalies.

Subjects and methods: a descriptive hospital-based prospective study in one year among newborn delivered baby in Bent Al-Huda Teaching Hospital, Thi-Qar Governorate, Iraq from January 2019 -December 2019. Both the mother and her baby were examined as a unit within 24 hours of birth A medical history was taken including parents age, residency, gestational age, and thorough physical examination of the baby was made. all baby with identified birth defects were admitted to neonatal care unit for observation, investigation, evaluation and management. The data were analyzed by simple statistical techniques recording number and percentage of cases.

Results: The overall prevalence of congenital anomalies among neonates was $\mathbf{1 . 2 6 \%}$. The first most prevalent congenital malformations were anencephaly $7.78 \%$, down syndrome $6.11 \%$, upper and lower limb malformation $6.11 \%$ hydrocephalus $9 \%$, heart malformation5\%. More than one system involvement was reported in $\mathbf{( 6 . 1 1 \% )}$ cases. Most congenital malformations occurred in male children $52.73 \%$ anomalies, $62 \%>2.5 \mathrm{Kg}$ body weight \&36.67\% in term baby. The highest congenital abnormality is reported among babies delivered by mothers aged 20-45 years of age (i.e.,94\%). More than $62 \%$ of urban resident.

Conclusion: nervous system anomalies, down syndrome, and musculoskeletal system anomalies are most prevalent congenital malformations in Thi-Qar while the low birth prevalence of other birth defect $1.26 \%$ may be a result of institutional and personal characteristics of the documentation system.

Recommendation: The more wide extensive screening programs to detect the exact prevalence, type, causes and distribution of birth defects is needed and implemented as health program. 
Web Site: $\underline{\text { https://jmed.utq.edu.iq }}$

ISSN (Print):1992-92 18, ISSN (Online):1992,92 18

DOI: https://doi.org/10.32792/utq/utjmed/19/1/2/0
Email:utjmed@utq.edu.iq
Key word: Prevalence, congenital

\section{Introduction:}

Congenital malformation or birth defect is defined as functional or structural(morphological) abnormalities, including metabolic disorders, that develop in the fetus and embryo from conception and present from birth or detected later (1). Regardless of definition, congenital disorder can cause still births and spontaneous abortions. They are a significant but under recognized cause of disability and mortality among infants and children under the age of five years. They can be life-threatening conditions, result in long-term disability, and negatively affect health - care system, societies, families and individual (2).

Congenital malformations are estimated to be $2-4 \%$ of all births. Despite their low prevalence rate, birth defects are responsible for nearly $30 \%$ of perinatal deaths, $\&$ considerable infant morbidity in developed countries. (3) .Worldwide published report on the prevalence of congenital disorders that ranges from 20-55 per 1000 live birth with significant differences according to the study design, method of case ascertainment and the study population (4).

Each year about 7.9 million are born with congenital disorder and several hundred thousand more are born with congenital malformation due to the insult after conception such as exposure to the teratogens and infections. (5). Annually 2.7 million newborn die, more than 1 in 10 die of birth disorder, and, overall 484000 deaths among children younger than 5 years of age. These figures underestimated malformation, prospective study.

because many children die with congenital malformation such as metabolic disorder and heart defects go undetected. (6)

Congenital disorder are multifactorial in origin , genetics factors,several nutrient deficiency, and environmental teratogens all of these affect the prenatal period. Maternal illnesses like diabetes mellitus (DM), maternal infections such as rubella folic acid and iodine deficiency, smoking ,alcoholism and radiation are all seems to be causes of contribute to congenital malformations (2).

Congenital defects can be of different types:

1. Structural abnormality: where structure or external form is abnormal.

2. Functional abnormality: where the organ function is affected, the effect can be at the level of the cell, where a specific enzyme may not be formed normally, such as in hemophilia a specific factor essential for clotting is absent.

3. Metabolic: where a metabolism due to absence or defect in one or more enzymes (7).

In the recent century with improving of life and progress in different sciences \& technology including medical fields ,introduction of antibiotics, vaccination \&immunoglobulin will lead to control decrease the prevalence of infectious disease which were the most cause of mortality in under five years of age . congenital malformation is one of the important recent problems that increased both morbidity and mortality.(8)

Maternal and child health is one of the most important indicator of healthy community. 
Web Site: https://jmed.utq.edu.iq

ISSN (Print):1992-92 18, ISSN (Online):1992,92 18

DOI: https://doi.org/10.32792/utq/utjmed/19/1/2/0
Email:utjmed@utq.edu.iq
So the study of incidence, prevalence risk factors ,distribution, and burden of the disease have apriority . (9).

Although, previous reports and studies discovered and documented various types of congenital malformations but the problems still increasing in its frequency with more disability, mortality and high burden of disease on individual and his or her family . so there is a need for more worldwide researches for good understanding of its distributions and risk factors . Low disease prevalence was reported in Japan $1.07 \%$ to high prevalence that reported in Taiwan 3\% this variable distribution could be attributed to the different study design used in the different studies (11).

This local study in AL-Nasiriya designed to report the pattern of neonatal congenital malformation

Aim : to estimate the prevalence of congenital malformations.

Specific objectives:

1- Most common type of birth defects.

2- Any factors that responsible or contribute to these anomalies.

\section{Patients and Methods:}

An unselected group including(180) newborn baby (95 males and 85 females) with documented congenital malformation were included in this prospective study. The mother of these newborn baby was attending the obstetric department in Bent Al-Huda Teaching Hospital, Thi-Qar
Governorate, Iraq from January 2019 December 2019.

Both the mother and her baby were examined as a unit within 24 hours of birth. A verbal consent had been taken from all participants, A full demographical, medical, obstetric and gynaecological histories was taken including parents age, residency, gestational age, and thorough physical examination of the baby was made. all baby with identified birth defects were admitted to neonatal care unit for further evaluation and investigated according to the case by blood sample ,sonography ,x-ray, some time echo when indicated with further mangment for each baby with its specific malformation. ICD-10 was used for classification and child with frequent anomalies counted only for one time according to serious anomaliy(2). Data were analyzed by simple statistical techniques recording number and percentage of cases. Spss version 23 for the analysis, $P$ value lower than 0.05 was a considerable limit for significance. A written consent was obtained from all local authorities before engagement within the study. 
Web Site: $\underline{\text { https://jmed.utq.edu.iq }}$

Email:utjmed@utq.edu.iq

ISSN (Print):1992-92 18, ISSN (Online):1992,92 18

DOI: https://doi.org/10.32792/utq/utjmed/19/1/2/0

\section{Results:}

Table 1 show the frequency $\& \%$ of congenital malformation the first most prevalent congenital malformations were anencephaly $\mathbf{7 . 7 8 \%}$, down syndrome, upper and lower limb malformation 6.11\% hydrocephalus, heart malformation $5 \%$.

Table 1. Type of congenital malformation in observed patients (No.180):

\begin{tabular}{|c|c|c|}
\hline Type of congenital malformation & No. & $\%$ \\
\hline Anencephaly & 14 & 7.78 \\
\hline Multiple malformation & 11 & 6.11 \\
\hline Downs syndrome & 11 & 6.11 \\
\hline Upper \&lower limb malformation & 11 & 6.11 \\
\hline Hydrocephalus & 9 & 5 \\
\hline Heart malformation & 9 & 5 \\
\hline Spina bifida & 8 & 4.44 \\
\hline Cleft lip & 8 & 4.44 \\
\hline Hydrocephalus \&spina bifida & 7 & 3.89 \\
\hline Abdomen malformation & 7 & 3.89 \\
\hline Leg malformation & 6 & 3.33 \\
\hline Intestinal malformation & 6 & 3.33 \\
\hline Cleft lip and palate & 5 & 2.78 \\
\hline Microcephaly & 4 & 2.22 \\
\hline Foot malformation & 4 & 2.22 \\
\hline Trachea-esophageal atresia & 3 & 1.67 \\
\hline Hydrocephalus \& limb malformation & 3 & 1.67 \\
\hline Hand and foot malformation & 3 & 1.67 \\
\hline Icthyosis & 3 & 1.67 \\
\hline Kidney \&foot malformation & 3 & 1.67 \\
\hline Ambiguous genitlia & 3 & 1.67 \\
\hline Polydactyl & 2 & 1.11 \\
\hline Imperforated anus & 2 & 1.11 \\
\hline Heart malformation \& brain cyst & 2 & 1.11 \\
\hline Chest \& kidney malformation & 2 & 1.11 \\
\hline Chest \& abdomen malformation & 2 & 1.11 \\
\hline Eye malformation & 2 & 1.11 \\
\hline Laryngeal & 1 & 0.56 \\
\hline Ear malformation & 1 & 0.56 \\
\hline Abdomen malformation and hydrocephalus & 1 & 0.56 \\
\hline Chest \& vertebral Colum malformation & 1 & 0.56 \\
\hline
\end{tabular}


Web Site: $\underline{\text { https://jmed.utq.edu.iq }}$

Email:utjmed@utq.edu.iq

ISSN (Print):1992-92 18, ISSN (Online):1992,92 18

DOI: https://doi.org/10.32792/utq/utjmed/19/1/2/0

\begin{tabular}{|c|c|c|}
\hline Spina bifida \& intestinal atresia & 1 & 0.56 \\
\hline Anencephaly, Spina bifida \&exomphalos & 1 & 0.56 \\
\hline Epiglottis & 1 & 0.56 \\
\hline Down \& cleft lip & 1 & 0.56 \\
\hline Left lower limb malformation & 1 & 0.56 \\
\hline Right lower limb malformation & 1 & 0.56 \\
\hline Syndactly & 1 & 0.56 \\
\hline Abdominal \&limb malformation & 1 & 0.56 \\
\hline Upper limb malformation & 1 & 0.56 \\
\hline Imperforated anus \& hand malformation & 1 & 0.56 \\
\hline Imperforated anus \& umbilical cord malformation & 1 & 0.56 \\
\hline Congenital anal mass & 1 & 0.56 \\
\hline Heart malformation \& down syndrome & 1 & 0.56 \\
\hline Heart malformation \&exomphalos & 1 & 0.56 \\
\hline Kidney malformation & 1 & 0.56 \\
\hline Umbilical cord malformation & 1 & 0.56 \\
\hline Congenital testicular malformation & 1 & 0.56 \\
\hline genitlia\&cleft lipAmbiguous & 1 & 0.56 \\
\hline Intestinal malformation \&cleft lip & 1 & 0.56 \\
\hline Psoriasis & 1 & 0.56 \\
\hline
\end{tabular}

Table 2 show the frequency and \% of the parent age of congenitally malformed baby ,97 of father \&94\% of mother of 20-45 years of age. More than $62 \%$ of urban resident.

Table 2 .frequency and \% of congenital malformation according to the parents age and residency:

\begin{tabular}{|c|c|c|c|}
\hline \multicolumn{2}{|c|}{ Variables } & \multicolumn{2}{l|}{} \\
\hline Parents age & No & $\%$ & p-value \\
\hline Father age & & & \\
\hline$<20$ years & 4 & 2.22 & 0.0001 \\
\hline $20-45$ & 176 & 97.78 & \\
\hline Mother age & & & \\
\hline$<20$ years & 10 & 5.56 & 0.001 \\
\hline $20-45$ & 170 & 94.44 & \\
\hline Residency & & & \\
\hline Urban & 113 & 62.78 & 0.012 \\
\hline Rural & 67 & 37.22 & \\
\hline Total & 180 & 100 & \\
\hline
\end{tabular}


Web Site: $\underline{\text { https://jmed.utq.edu.iq }}$

Email:utjmed@utq.edu.iq

ISSN (Print):1992-92 18, ISSN (Online):1992,92 18

DOI: https://doi.org/10.32792/utq/utjmed/19/1/2/0

Table 3 show the frequency and percentage of malformed baby according to their sex weight and gestational age, the prevalence of congenital malformation was more common among male $52.73 \%$ as compared to female $46.67 \%$, more than $62 \%$ of $>2.5 \mathrm{Kg}$ and $36.67 \%$ of $\geq 37$ weeks of gestations.

Table 3. Frequency and \% of congenital malformation according to the sex, weight, gestational age and mode of delivery:

\begin{tabular}{|l|l|l|l|}
\hline Variable & No. & $\%$ & P value \\
\hline Sex & & & \\
\hline Male & 95 & 52.73 & 0.134 \\
\hline Female & 84 & 46.67 & \\
\hline Weight & & & \\
\hline$<1$ KG & 2 & 1.11 & \\
\hline $1-2.5 \mathrm{Kg}$ & 66 & 36.67 & $\mathbf{0 . 0 1 4 3}$ \\
\hline$>2.5 \mathrm{Kg}$ & 112 & 62.22 & \\
\hline Gestational age & & & \\
\hline$<37$ & 27 & 15.00 & \\
\hline$\geq 37$ & 66 & 36.67 & \\
\hline Total & & & \\
\hline
\end{tabular}

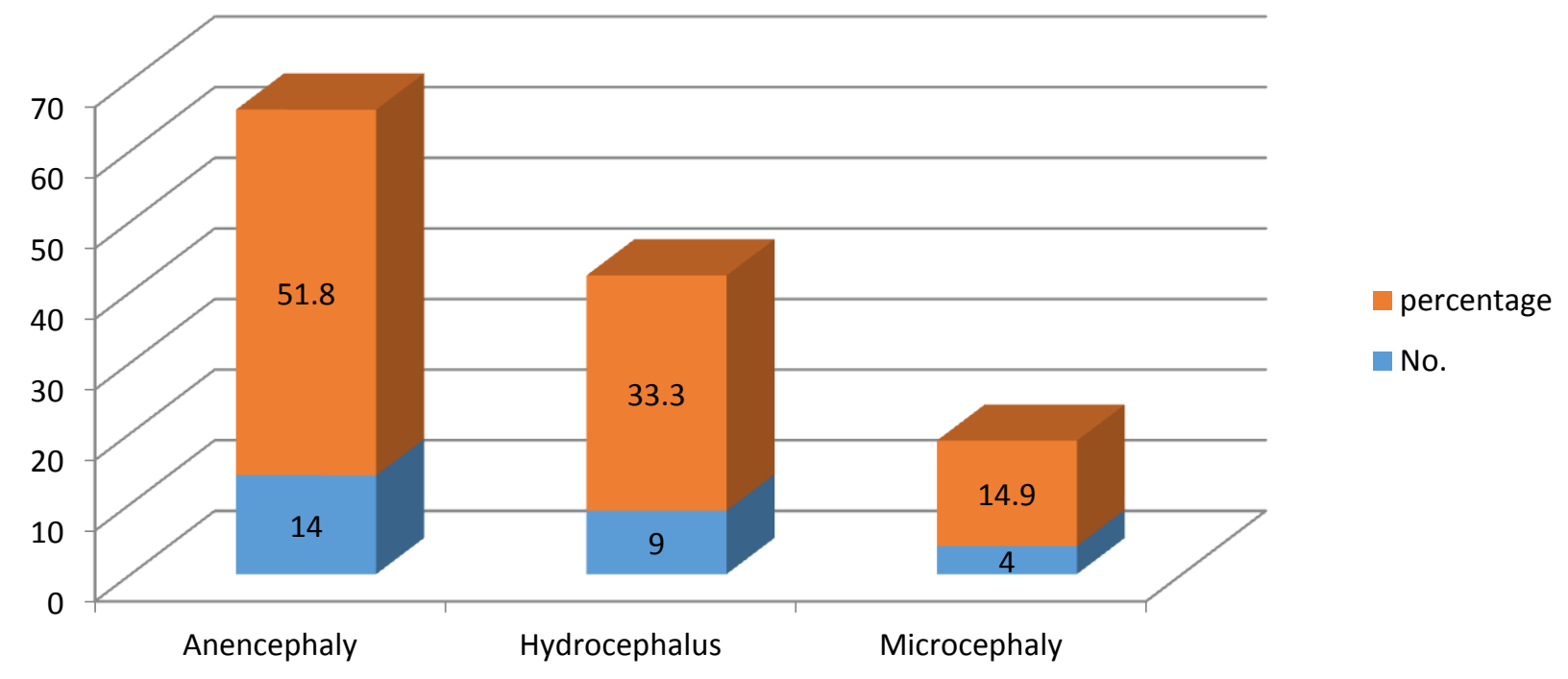


Thi-Qar Medical Journal (TQMJ):Vol.(19), No.(1), 2020

Web Site: https://jmed.utq.edu.iq

Email:utjmed@utq.edu.iq

ISSN (Print):1992-92 18, ISSN (Online):1992,92 18

DOI: https://doi.org/10.32792/utq/utjmed/19/1/2/0

Figure 1: Common CNS anomalies

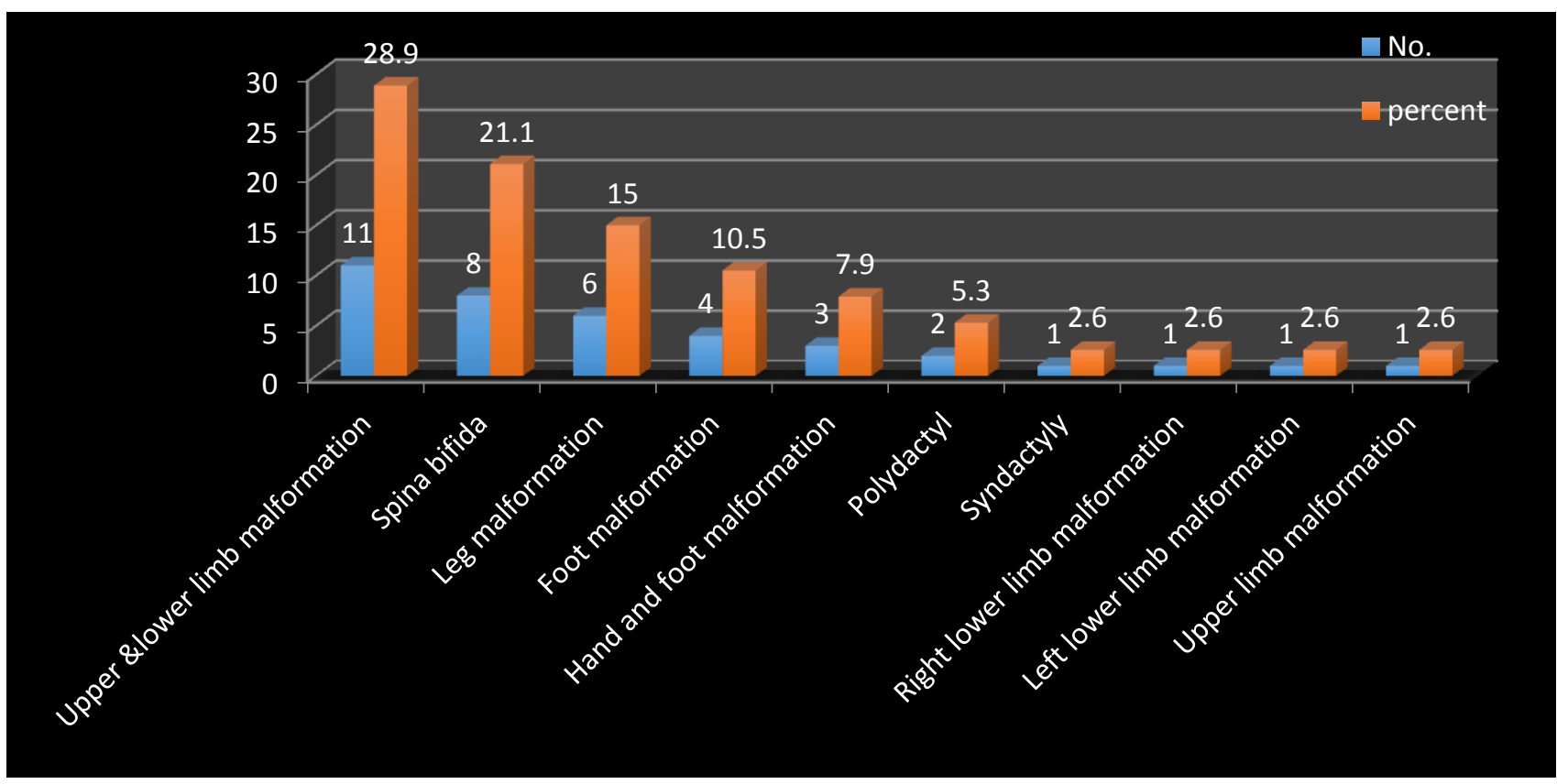

Figure 2: Common Musclo- Skeletal anomalies

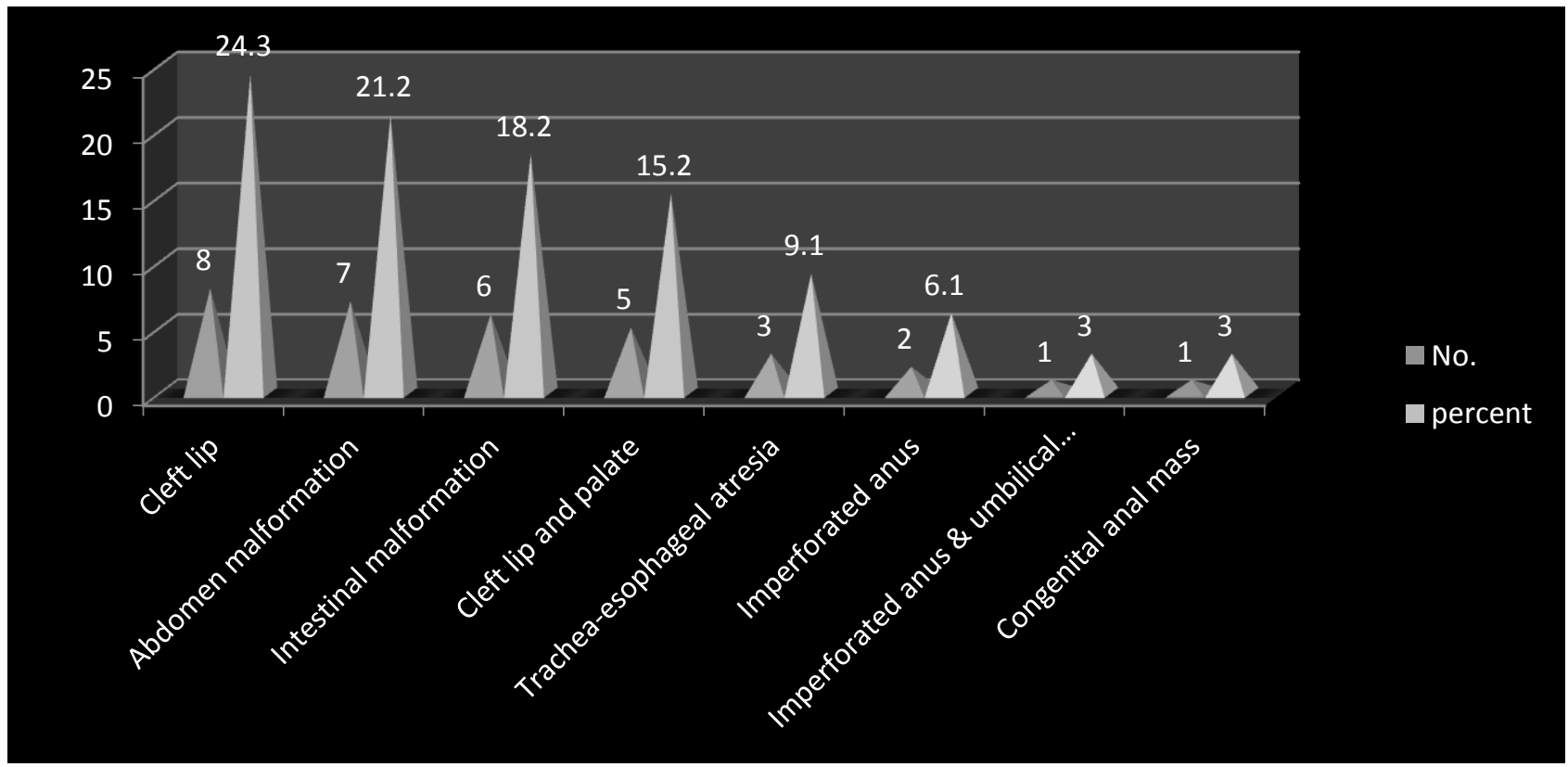


Web Site: $\underline{\text { https://jmed.utq.edu.iq }}$

ISSN (Print):1992-92 18, ISSN (Online):1992,92 18

DOI: https://doi.org/10.32792/utq/utjmed/19/1/2/0
Email:utjmed@utq.edu.iq

Figure 3: Common GIT anomalies

\section{Discussion:}

In the last decade there was improvement in the control of infectious disease and nutritional deficiency diseases, so the congenital malformations have become one of the important factors of perinatal mortality in developed countries and a good sensitive indicators of perinatal death in a developing country(11).

Nearly ,66\% of major birth defects have no detectable and recognized cause, and most of these malformation due to multifactorial inheritance (12).

In developed countries the prevalence of birth defects between 3-5\%(13). The overall prevalence of congenital malformation in the present study is $1.26 \%$,these results in accordance with finding reported in Kuwait study by Madiet al.(14) who documented an prevalence of $1.25 \%$, India study by Swain et al.(11) who found that, an prevalence of $1.2 \%$, in the study of United Arab Emirates(15) and in Egypt study : 1.58\% in Cairo (16 ) and $1.16 \%$ in Alexandria(17) .It is lower than Erbil study $3.5(18) \%$ and Turkey $3.65 \%(19)$ These differences in prevalence of congenital anomalies in different countries of the world might be due to several factors such as social and racial effects that are specially in inherited disease. Also the results of different study vary depending on the study design, sample size and the period of observation (20).

The present study revealed that

1- the most common birth defects were related to nervous system (Anencephaly $7.78 \%$ \& Hydrocephalus 5\%) it is consistent with Erbil study (18) \& the second most prevalent system was musculoskeletal
$6.11 \%$, it is similar to the finding of Egypt study (21). More than one system involved in $6.11 \%$ of the studied sample.

2- The prevalence of congenital anomalies was more common among parents age 20-40 years $(94 \%$ mother \& $97 \%$ of father) ,it was consistent with Erbil study $50.72 \%$ in the mother of $30-45$ years old (8). So that older age group mothers need to be examined more carefully due to the risk of the birth of a congenitally malformed baby is higher.

3- The prevalence was slightly more common among male $52 \%$ as compared to females 46\%) . Many studies have reported male preponderance of congenital malformation $(22,23)$,

4-it was more common among urban $62 \%$ as compared to the rural area $37 \%$ ) these could be attributed to the pollution in the urban areas.

\section{Conclusion:}

the most prevalent congenital malformations in Thi-Qar are as follows: nervous system anomalies, down syndrome, and musculoskeletal system anomalies. IN this study, the low birth prevalence of birth defect $1.26 \%$ may be a result of institutional and personal characteristics of the documentation system.

\section{Recommendation}

this study was included the records of last one year only so there is a need for further studies to document the risk factor and causes of these anomalies. Furthermore, 
Web Site: $\underline{\text { https://jmed.utq.edu.iq }}$

ISSN (Print):1992-92 18, ISSN (Online):1992,92 18

DOI: https://doi.org/10.32792/utq/utjmed/19/1/2/0

there is a need for more wide extensive screening programs to detect the exact
Email:utjmed@utq.edu.iq prevalence, type, causes and distribution of birth defects. nation-wide screening studies to determine the birth prevalence, and types and distribution of congenital anomalies.

\section{References:}

1.Hamamy H. Primary prevention of congenital disorder. Training course in sexual and reproductive health research $; 2011$.

2. World Health Organization. Birth defects. Executive Board, 126th session, provisional agenda, December 2009; EB 126/10, 3. Available form: http://apps.who.int/gb/ebwha/pdf_files/EB1 26/B126_10-en.pdf)

3. Steele MW, Breg WR (1966) chromosome analysis of human amniotic fluid. lancet 1(7434:383-385).

4.Parker SE, Mal CT, Rickard R, Wang Y, Meyer RE, et al. Updated national birth prevalence estimates for selected birth defects in the united states. Birth defects Res A ClinMolTeratol2010; 88:1008-16.

5.Christianson A, Howson C, Modell B. March of Dimes Global Report on Birth Defects: The Hidden Toll of Dying and Disabled Children. White Plains, NY: MarchofDimesBirthDefectsFoundation;2006.

6- global, regional, and national causes of child mortality in 2000-13, with projections to inform post-2015 priorities).

7.Parker SE, Mal CT, Rickard r, Wang Y, Myer RE, et al. Factors responsible for congenital anomalies, 2004 -2006.Birth defects Res A ClinMolTeratol 2010;88:1008-16.

8. Singh A, Gupta RK. Pattern of congenital anomalies in newborn: a hospital based prospective study. JK Science 2009; 2:34-6). 
ISSN (Print):1992-92 18, ISSN (Online):1992,92 18

DOI: https://doi.org/10.32792/utq/utjmed/19/1/2/0

9. Cassell CH, Golden L. Epidemiology as a guardian of children's health: translating birth defects research into policy. Ann Epidemiol 2010; 20:493-8).

10. Jehangir W, Ali F, Jahangir T, Masood MS. Prevalence of gross congenital malformations at birth in the neonates in a tertiary care hospital. APMC 2009; 3:47-50).

11.Swain S, Agrawal A, Bhatia BD. Congenital malformations at birth. Indian Pediatr1994; 31:1187-91.

12. Hudgins L, Cassidy SB. (2006). Congenital anomaly. Martin RJ, Fanaroff AA, Walsh MC. Fanaroff and Martin, $s$ NeonatalPerinatal Medicine Diseases of the Fetus and infant, , 8 th edition, Elisvier, Philadelphia . Pp: 561-581.

13. Göynümer FG, Kepkep K, Yetim G, Tuncay Y, et al. (2005). DogumlardaMajörKonjenitalAnomalilerinRetrospektifAnalizi(Retrospective analysis of major congenital anostopdeadmalies at birth). Perinatol. Dergisi 13: 31-34.

14.Madi SA, Al-Naggar RL, Al-Awadi SA. Bastaki LA. v. East Mediterr Health J 2005;11:700-6.

15.Al-Ghazali LI. The profile of major congenital abnormalities in the United Arab Emirates (UAE) population. J Med Genet 1995; 32:7-13.

16.Hafez M, El Sabrawy M, El Salab SH, et al. Study of congenital malformations in Egypt. Egyptian J Pediatr1985; 2:69-93.

17.Stevenson AC, Johnston HA, Stewart MI, et al. Congenital malformations. A report of series of consecutive births in 24 centers. Bull World Health Organ 1966;34 Suppl:9-127.

18.Othman GO.The prevalence and types of congenital anomalies in newborns in Erbil ,2013.

19.Tunçbilek E (2001). Clinical outcomes of consanguineous marriages in Turkey. Turk. J. Pediatr. 43: 277-27 
Thi-Qar Medical Journal (TQMJ):Vol.(19), No.(1), 2020

Web Site: https://jmed.utq.edu.iq

Email:utjmed@utq.edu.iq

ISSN (Print):1992-92 18, ISSN (Online):1992,92 18

DOI: https://doi.org/10.32792/utq/utjmed/19/1/2/0

20.Jehangir W, Ali F, Jahangir T, Masood MS. Prevalence of gross congenital malformations at birth in the neonates in a tertiary care hospital. APMC 2009; 3:47-50.

21. El Koumi MA ,Al Banna EA, Lebda I. Pattern of congenital anomalies in newborn: a hospital-based Study.Pediatric report 2013.

22. Mandiracioğlu A, Ulman I, Lüleci E and Ulman C (2004). The incidence and risk factors of neural tube defects in Izmir, Turkey: a nested case-control study. Turk. J. Pediatr. 46: 214220.

23. Hollier LM, Leveno KJ, Kelly MA, McIntire DD, et al. (2000). Maternal age and malformations in singleton births. Obstet. Gynecol. 96: 701-706. 
Thi-Qar Medical Journal (TQMJ):Vol.(19), No.(1), 2020

Web Site: https://jmed.utq.edu.iq

Email:utjmed@utq.edu.iq

ISSN (Print):1992-92 18, ISSN (Online):1992,92 18

DOI: https://doi.org/10.32792/utq/utjmed/19/1/2/0

التشوهات الخلقية في محافظة ذي قار: دراسة رصد حديثة للعام 9 1 م

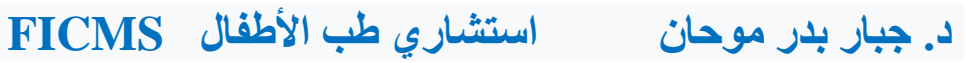

DCh دمحد عزيز كاطع

DCh دريكان محسن زغير

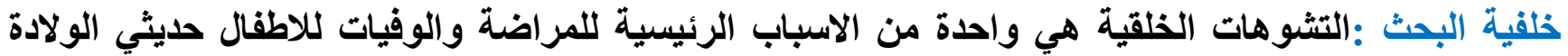

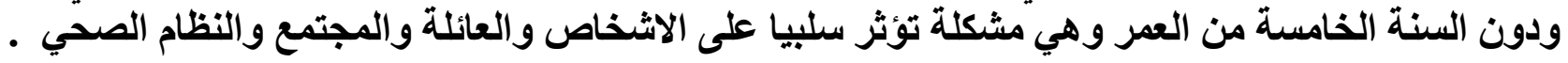
الهدف : دراسة معدل انتشار التشوهات الخلقية والانواع الاكثر شيوعا والعوامل المرتبطة بها.

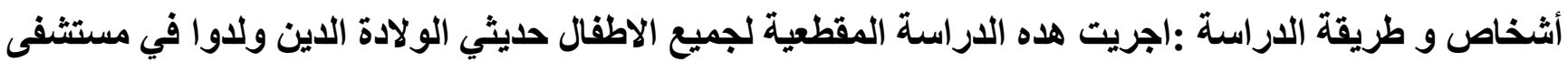

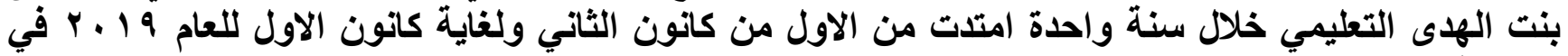

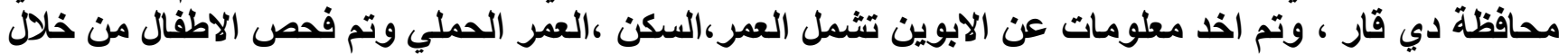
اخد الوزن والمراقبة واجراء الفحوصات المختبرية والتقييم والعلاج.وتم تحليل البيانات من خلال التهل حساب الترددات و النسبة المئوية.

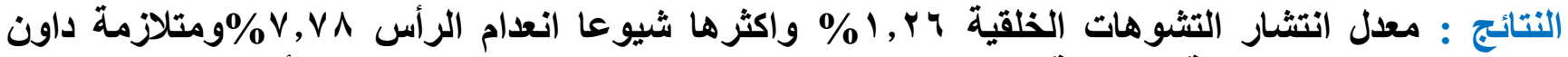

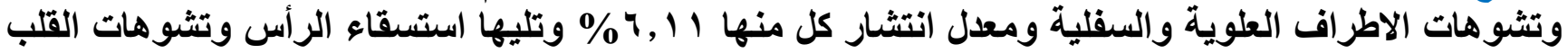

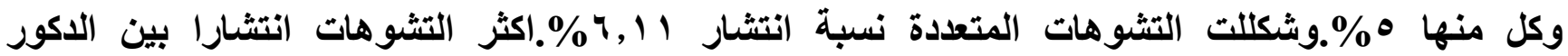

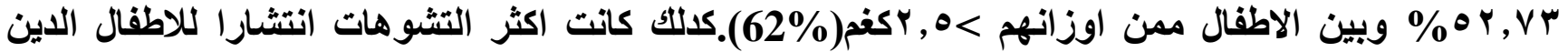

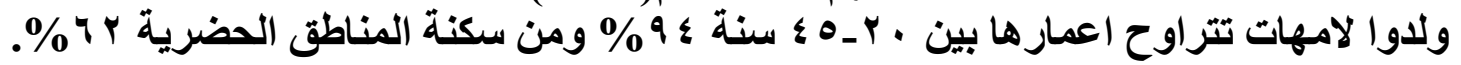

الاستنتاجات : اكثر التشوهات شيوعا هي انعام الرأس ،متلازمة داون، تثوهات الاطراف العلوية والسفلية

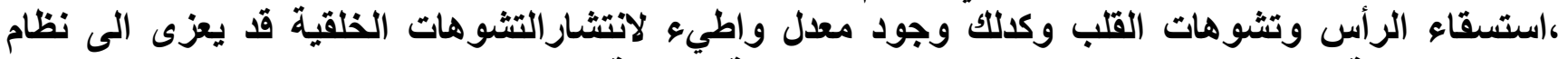
التوثيق بالنسبة للاثخاص العاملين وعلى مستوى المؤستسة وكئ الصحية. 